\title{
PEDAGOGICAL VIEWS OF S. MYROPOLSKY \\ ON THE CONTENTS OF PRIMARY EDUCATION
}

\section{ПЕДАГОГІЧНІ ПОГЛЯДИ С. МИРОПОЛЬСЬКОГО НА ЗМІСТ ПОЧАТКОВОЇ ОСВІТИ}

\section{Holiuk Oksana ${ }^{1}$ \\ Rodiuk Nataliia ${ }^{2}$}

http://dx.doi.org/10.30525/978-9934-571-27-5_14

Abstract. The article is devoted to the integral analysis of S. Miropolsky`s didactic views. The peculiarities of the teacher's approach to the essence of the learning process are discovered: the structural components of the content of education are revealed, and the pedagogical requirements to it are grounded.

The subject of the study is S. Miropolsky`s didactic views. The purpose of the research is to determine the contribution of the teacher to the development of the theory of learning, based on the analysis and systematization of historical and pedagogical sources, educational and methodical literature, archival documents, materials of the national periodicals of the XIX century and the pedagogical heritage of S. Miropolsky.

The methodological basis of the research is the concept of state-building in Ukraine, updating and democratization of all spheres of social and economic life of the society; the theory of scientific knowledge; the dialectical materialistic positions on the interconnection of the national and the universal, on the advisability of the creative using the heritage of outstanding teachers in modern pedagogical practice. The research is based on the principles of historicism, systematic, scientific, creative approach to the individual as a subject of the educational process.

Study of the pedagogical heritage of S. Miropolsky, analysis of historical and pedagogical literature on the topic of research, archival documents

${ }^{1}$ Candidate of Pedagogic Sciences, Associate Professor,

Head of Department of Pre-school and Primary Education,

Vinnytsia State Pedagogical University named after Mykhailo Kotsiubynsky, Ukraine

${ }^{2}$ Candidate of Philological Sciences,

Associate Professor at Department of Pre-school and Primary Education,

Vinnytsia State Pedagogical University named after Mykhailo Kotsiubynsky, Ukraine 
allowed to establish the teacher's contribution to the development of theoretical and practical issues of didactics.

S. Myropolsky in his pedagogical searching relied on the pedagogical ideas of Y. Komensky, as well as the achievement of progressive domestic pedagogical thought, as reflected in the writings of M. Korf, M. Pirogov, V. Stoyunin, K. Ushinsky and others. He supported and developed the ideas of Christian education, general education, school democratization, and educational training.

Considering the issues of education in connection with the tasks of social and moral development of society in specific historical conditions, S. Miropolsky understood learning as a two-way process. S. Miropolsky advocated the equality of girls and boys in obtaining the education. The merit of the teacher was: a) inclusion the components of the universal development and elements of the national and practical education in the content of education; b) the formulation of certain requirements regarding the content of education.

The result of the development of theoretical issues related to the organization of the learning process was the substantiation of the stages of mastering the educational material and their "structural elements of assimilation" (attraction of attention, organization of perception, comprehension, consolidation of perceived and assimilated information, knowledge control), as well as the definition of teacher's functions - guarding and guiding.

\section{1. Ветуп}

Педагогічна наука і шкільна практика сьогодні знаходяться у стані пошуку оптимальних шляхів реалізації творчої діяльності особистості, розвитку демократизації навчально-виховного процесу. Основною метою програми «Освіта. Україна XXI століття» $є$ визначення стратегії розвитку освіти в Україні й створення життєздатної системи безперервного навчання для досягнення високих освітніх рівнів і забезпечення можливостей постійного духовного самовдосконалення особистості та формування інтелектуального потенціалу як найвищої цінності нації. У новому Державному стандарті початкової освіти зазначено, що іiі метою є гармонійний розвиток дитини відповідно до ії вікових та індивідуальних психофізіологічних особливостей і потреб, виховання загальнолюдських цінностей, підтримка життєвого оптимізму, розвиток самостійності, творчості та допитливості. 


\section{Holiuk Oksana, Rodiuk Nataliia}

Таким чином, у сучасних умовах проблема науково-методичного забезпечення навчально-виховного процесу набуває актуального значення. Саме це підсилює особливий інтерес до вітчизняної історії освіти і виховання. Без знання того, як розвивалась теорія і практика навчання і виховання молодих поколінь у минулому, неможливо вирішити нагальні питання.

Сучасна дидактика базується на ідеях відомих зарубіжних педагогів та представників просвіти, у той час, як педагогічна спадщина українських педагогів ще детально не вивчена. Відродження забутих імен національних діячів - імпульс для розвитку дидактики в сучасній національній школі. У зв'язку з цим педагогічна спадщина педагогів другої половини XIX століття представляє глибокий інтерес для педагогічної науки і практики.

Слід відзначити, що вагомий внесок у вирішення сучасних проблем дидактики внесли Ю.К. Бабанський, М.О. Данилов, Б.П. Єсипов, М.М. Скаткін. Серед українських дослідників сучасних дидактичних питань виділяються праці В.І. Лозової, О.В. Онищука, В.Ф. Паламарчука, О.В. Савченко.

Величезна кількість прогресивних ідей, що були висунуті педагогами-просвітянами минулого, не втратили своєї актуальності й у наш час. Тому великий інтерес зараз викликає педагогічна спадщина українських педагогів XIX століття: Х.Д. Алчевської, С.В. Васильченка, Б.Д. Грінченка, М.І. Демкова, О.В. Духновича, К.В. Єльницького, П.Ф. Каптерева, М.О. Корфа, С.О. Рачинського, К.Д. Ушинського тощо, вивченням яких присвячені кандидатські дисертації І. Грушкевича, М. Коваля, В. Лаврив, О. Неживого.

Значний внесок у розробку теорії і практики виховання й освіти зробив вітчизняний педагог XIX століття C.I. Миропольський. Про нього, як про вченого і педагога, згадували М.О. Корф, С.О. Рачинський, К.В. Сльницький, М.І. Демков, В.Я. Абрамов, Д.І. Багалій та ін.

Педагогічні праці C.I. Миропольського можна зустріти в таких історичних та літературних виданнях: «Наша початкова школа», «Журнал Міністерства Народної Просвіти», пам’ятній книжці Харківської губернії на 1868 рік, Харківському календарі на 1869 і 1870 роки, монографії Д.І. Багалій та Д.П. Міллер «Історія міста Харкова за 250 років його існування». 


\section{Pedagogical views of S. Myropolsky on the contents of primary education}

Педагогічна спадщина C.I. Миропольського відрізняється величчю та багатогранністю. Він, спираючись на дидактику Я.А. Коменського, К.Д. Ушинського, розвинув та поглибив теорію і практику шкільної освіти, висунув широку просвітницьку програму, що відповідає інтересам народних мас. Практична і теоретична діяльність С.I. Миропольського проштовхнула вітчизняну педагогіку, закріпила в ній прогресивні ідеї суспільного педагогічного руху в Україні та Росії у другій половині XIX століття.

Загальна характеристика педагогічних поглядів та діяльності C.I. Миропольського подана в дисертаційному дослідженні М.М. Головкової (1994р.). Специфіка його поглядів відносно виховуючого навчання розкрита в дослідженні С.Т. Золотухіної (1995р.).

Мета дослідження - на основі аналізу та систематизації історико-педагогічних джерел, навчально-методичної літератури, архівних документів, матеріалів вітчизняної періодики XIX століття та педагогічної спадщини C.I. Миропольського, визначити внесок педагога у зміст початкової освіти.

Завдання дослідження:

1. Визначити концептуальні положення, що покладені в основу дидактичної системи С.I. Миропольського.

2. Розкрити специфіку поглядів C.I. Миропольського на сутність навчання.

3. Виявити і охарактеризувати компоненти змісту освіти.

Методологічною основою дослідження є концепція державотворення в Україні, оновлення та демократизації всіх сфер соціально-економічного життя суспільства; теорія наукового пізнання; діалектико-матеріалістичні положення про взаємозв язок національного та загальнолюдського, про доцільність творчого використання спадщини видатних вітчизняних педагогів у сучасній педагогічній практиці. Дослідження базується на принципах історизму, системності, науковості, творчого підходу до особистості як суб`єкта навчально-виховного процесу.

Наукова новизна даного дослідження полягає у тому, що вперше подається цілісний аналіз дидактичних поглядів C.I. Миропольського, розкрито особливості підходу педагога до сутності процесу навчання; визначено мету, завдання навчання, виявлено етапи засвоєння навчального матеріалу й адекватні їм структурні елементи засвоєння, функції 
вчителя в процесі викладання;виявлено структурні компоненти змісту освіти і обгрунтовані педагогічні вимоги до нього.

\section{2. Сутність процесу навчання за С.I. Миропольським}

Однією з основних проблем педагогіки XIX століття була проблема «чого вчити і як учити». По-своєму вирішував iï і C.I. Миропольский. Як показав аналіз його історико-педагогічної спадщини, в основу його дидактичних переконань було покладено ідеї, висловлені Я.А. Коменським у «Великій дидактиці».

Поняття «процес навчання» належить до початкових у педагогіці і визначається як двосторонній процес, у ході якого здійснюється взаємозв'язок учителя і учнів, спрямований на засвоєння школярами основ накопиченого суспільством соціального досвіду, виховання і розвиток учнів [4, с. 3]. С.I. Миропольский, як свідчить вивчення його педагогічної спадщини, розглядав процес навчання як частину цілісного педагогічного процесу і виділяв його основні компоненти: викладання (діяльність учителя) і навчання (діяльність учнів).

У роботах «Дидактичні нариси. Учень і виховне навчання в народній школі», «Народна школа за ідеями Коменського», «Навчання грамоті» C.I. Миропольский відзначав, що в процесі навчання повинне здійснюватися засвоєння учнями знань, умінь і навичок, розвиватися пізнавальні здібності учнів, їх уміння самостійно працювати. Вважаючи, що діяльність учителя має бути спрямована не стільки на повідомлення готових відомостей, скільки на «усебічне збудження розумової природи дитини», C.I. Миропольский справедливо вказував на те, що учитель в процесі викладання повинен збуджувати і підтримувати самостійність учня, зміцнювати його сили і здібності, при цьому уникати наказів, що обмежують силу самодіяльності, педантизму і формалізму. Цю ж точку зору підтримували багато педагогів того часу: M.О. Корф, П.Ф. Каптерев, К.В. Єльницький, M.І. Демков та інші.

Як показало проведене нами дослідження, одне з істотних завдань процесу навчання C.I. Миропольський вбачав у «збудженні допитливості дітей в якомога більшій кількості напрямів». Внаслідок того, що допитливість за своєю природою властива кожній людині, учитель у процесі навчання, підкреслював педагог, повинен реалізувати принаймні дві функції: «охоронну» - не заважати розвитку і вияву інтелектуальних інстинктів дитини, і «спрямовуючу» - давати потребі, 
що пробудилася, матеріал, який сприяв би ії правильному вихованню, «наводити діяльну силу на пряму дорогу» [9, с. 311].

У «Підручнику $з$ дидактики» (1901р.) С.І. Миропольський писав, що навчання - це процес оволодіння знаннями, що вивчаються, уміннями і навичками і застосування їх на практиці. Головною характеристикою цього процесу він вважав «самостійність під керівництвом учителя».

Розглядаючи навчання як цілісний процес, C.I. Миропольський чітко виділив етапи засвоєння навчального матеріалу й адекватні їм «структурні елементи засвоєння». Він вважав, що будь-яке навчання повинне розпочинатися з постановки учням мети. Спочатку передбачається притягнути увагу учнів: запропонувати послухати, подивитися. Надалі постановка мети ускладнюється у вигляді завдань різного типу, постановки питань, завдань практичного і пізнавального характеру.

Наступним етапом навчання C.I. Миропольський вважав організацію сприйняття цієї нової інформації і ії осмислення так, щоб, «спираючись на збудження самодіяльності учня і впливаючи на розум його, створити в ньому можливість іти свідомо до мети». Сергій Іринейович Миропольський відзначав, що на цьому етапі завдання вчителя полягає не в повідомленні готових знань, а в умінні змусити учня самого «усе катувати, вивчати, досліджувати».

На етапі закріплення сприйнятої і засвоєної інформації, як відзначав C.I. Миропольський, завдання вчителя полягає в тому, щоб «з одного і того ж матеріалу, видозмінюючи, відтворити предмет знову, даючи повний простір самодіяльності учнів» [9, с. 312].

Як відомо, для того, щоб учителеві знати, як іде процес засвоєння, потрібний зворотний зв'язок. 3 цією метою, на думку C.I. Миропольського, потрібний контроль знань, який він пропонував проводити у формі опитування. Він підкреслював, що в того вчителя, який володіє мистецтвом опитування, «увесь клас живе, усі натхненні, зацікавлені, усі беруть участь у вирішенні цих питань, уми і увага всіх у постійній напрузі» [9, с. 313].

Відзначимо, що всі запропоновані й описані C.I. Миропольським етапи процесу навчання в цілому відповідають сучасному процесу навчання, в якому не завжди вони позначаються в явному вигляді, а можуть «поєднуватися, опускатися і чергуватися». Навчання в сучасній школі вирішує три найважливіші задачі: здобування школярами 


\section{Holiuk Oksana, Rodiuk Nataliia}

знань, розвиток учнів і формування ставлення до навколишнього світу, тобто виховання. Як показало вивчення педагогічних робіт педагога, такі ж завдання висував перед процесом навчання і C.I. Миропольський. Він справедливо вважав, що діти повинні виходити зі школи, не лише маючи знання. Цього дуже мало. Вони повинні мати розвинений розум, пробуджену допитливість, навичку і любов до праці, завдатки здорового, чесного характеру, любов до правдивості, повагу до людської особистості, прагнення до самоосвіти і навичку свідомо підкорятися вимогам закону (дисципліні) [9, с. 117].

Заслугою C.I. Миропольського $є$ те, що він один 3 перших у вітчизняній педагогіці ввів поняття «виховне навчання» [3, с. 78]. Він відзначав, що в навчально-виховний процес «входить учень, учитель і виховне навчання». При цьому, підкреслював він, виховне навчання обов'язково має зважати на індивідуальність учня, що вимагає грунтовного і всебічного знайомства 3 ним. C.I. Миропольський писав: «Тільки тоді учитель в змозі надати виховний характер навчанню, коли між ним і учнем встановиться міцний і вільний, заснований на взаємній любові, довірі і повазі моральний зв’язок» [5, с. 225].

На думку C.I. Миропольського, навчання «є не метою, а засобом» для досягнення цілей, що стоять перед школою. Тому він також, як i I.Ф. Гербарт, і Ф.А.В. Дистервег, вважав, що однією із закономірностей процесу навчання $\epsilon$ те, що навчання в школі не повинне відокремлюватися від виховання, і «було б непослідовно у вихованні брати за основу одне, а в навчанні - інше» [7, с. 41; 9, с. 115]. C.I. Миропольський порівнював виховне навчання з мистецтвом. Він підкреслював, що якщо в мистецтві художник повинен добре ознайомитися зі своїм матеріалом, щоб утворити 3 нього художній твір, то тим більше це потрібно для педагога, «матеріалом діяльності якого є не мертва матерія, а жива істота».

Тісний взаємозв'язок виховання і навчання C.I. Миропольський вбачав у загальній педагогічній основі. Він відзначав, що знання засвоюються розумом, але здобуття знань вимагає зусилля волі, а почуття проникають в усю психічну діяльність дитини. Педагог підкреслював, що почуття задоволення і радості, що супроводжують навчання, полегшують його, а неприхильність, навпаки, обтяжує заняття, оскільки те, «що людині хочеться, то легше досягається». Але для «хотіння», вважав C.I. Миропольський, потрібне знання того, що можна хотіти. Цим 


\section{Pedagogical views of S. Myropolsky on the contents of primary education}

він і пояснив той факт, що воля знаходиться в психологічному зв'язку зі знанням, а знання залежить від волі [9, с. 115].

Слід особливо підкреслити своєрідність і динаміку поглядів C.I. Миропольського на мету і завдання навчання. У роботі «Народна школа за ідеями Коменського» (1873 р.) C.I. Миропольський, як і Я.А. Коменський, стверджував, що основною метою навчально-виховного процесу є всебічний і рівномірний (гармонійний) розвиток особистості. Але вже в 1890 році в роботі «Дидактичні нариси. Учень і виховне навчання в народній школі» Сергій Іринейович Миропольський вказував на необгрунтованість цього твердження. Він виступив проти терміну «гармонійний розвиток», вважаючи, що «цей термін неправдивий, не представляє нічого ясного, визначеного, грунтовного, довільно, хистко, суперечливо». Педагог відзначав, що справа виховання і навчання живої людської особистості настільки важлива і відповідальна, що в ії зміст не можна вносити нічого неясного, невизначеного, одностороннього, а тим більше хисткого і неправдивого, i вважав марним шукати цей зміст у «вигадках людських». На думку C.I. Миропольського, знайти іï можна тільки у того, хто сказав: «Я шлях, істина і життя». С.І. Миропольський писав: «Христос є істинна основа всякого християнського виховання - церковного, домашнього, шкільного, громадського, - й іншої основи ніхто не може покласти. У слові Божому ми знаходимо систему виховання, 3 якою не може порівнятися жодна 3 систем людських, а всі священні писання є богодуховенними і корисними для навчання» [7, с. 36-39].

Одним 3 головних соціально-педагогічних питань досліджуваного періоду було питання про загальне й обов' язкове навчання. Як свідчать архівні документи Розпорядчого відділу Харківської міської управи, 3 другої половини 60-х років багато земств зверталися до Міністерства народної просвіти 3 клопотанням про введення обов'язкового навчання [14]. Підкреслюючи появу багатьох досліджень 3 цього питання, Міністерство відзначало, що серед них найповнішою і доказовішою $\epsilon$ праця С.I. Миропольського «Школа і Держава. Обов'язковість навчання в Росії. Історичний етюд» (1876 р.). У цій роботі С.І. Миропольський виклав такі переваги обов'язкового навчання:

1. Обов'язкове навчання поставить школу в очах народу в правильне і високе положення, підніме ії авторитет. Школа стане освітнім інститутом для всіх. 


\section{Holiuk Oksana, Rodiuk Nataliia}

2. «Обов’язковість», будучи визнаною законом, перенесе справу народної освіти з області випадковості в «позитивну сферу розумної свідомості і зі сфери благих бажань в область практичної участі».

3. «Обов'язковість» зробить школу близькою народу, знищить розлад сім'ї зі школою.

4. «Обов’язковість» дозволить правильно організувати, упорядкувати відвідування школи учнями; дасть можливість вести справу навчання правильно, тямущо, без перерв, 3 корисними результатами. Зі школи виходитимуть учні, що дійсно отримали початкову освіту, здатні до самоосвіти.

5. «Обов'язковість» дозволить заснувати школи для дорослих, оскільки з'явиться контингент грамотних осіб, бажаючих поповнити свої знання.

6. «Обов'язковість» створить умови для облаштування шкіл сільськогосподарських, необхідних для покращення сільського побуту народу.

7. «Обов'язковість» уперше узаконить навчання дівчат.

8. «Обов'язковість» усуне «прикрі явища», коли і відкриті школи місцями закриваються, а в багатьох випадках перебувають порожніми.

9. «Обов'язковість» сприятиме з'ясуванню взаємних обов'язків суспільства і держави у справі народної освіти.

10. «Обов’язковість» освіти зрівняе витрати на школи, зробить неможливим повне їх ігнорування.

11. «Обов’язковість», надаючи міцне і позитивне значення школі, викличе до школи велику участь у суспільстві.

12. «Обов’язковість» прославить інститут учителів, їх значення $\mathrm{i}$ працю.

13. «Обов'язковість» зробить благотворний вплив на учнів, забезпечивши їх повним проходженням курсу початкової школи.

14. «Обов'язковість» дозволить кожному селянинові отримати безкоштовну освіту.

15. «Обов'язковість» послужить засобом для усунення ранньої і згубної експлуатації дитячої праці на фабриках і заводах.

16. «Обов'язковість» 3 морального боку задовольнить вимоги права, справедливості, зробивши освіту доступною для всіх, «прославивши це право і зробивши його обов'язком».

17. «Обов’язковість» 3 юридичного боку зробить доступними для народу вимоги закону. 


\section{Pedagogical views of S. Myropolsky on the contents of primary education}

18. «Обов’язковість» навчання сприятиме розвитку в народі прямих і вірних понять відносно особистих і громадських обов'язків у шкільній справі.

19. Збігаючись 3 природними обов'язками батьків щодо дітей, обов'язкове навчання дасть нову гарантію, що ці обов'язки, що надавалися раніше напризволяще, не можуть бути далі порушені безкарно.

20. «Обов'язковість» навчання благотворно вплине на економічний побут народу [11, с. 370-374].

Як бачимо, в основі поглядів педагога на процес навчання, на необхідність його організації, на перевагу обов'язкового навчання людей усіх прошарків лежить демократизм і гуманізм.

Аналіз вищевикладених положень щодо переваг обов'язкового навчання, сформульованих C.I. Миропольським, свідчить про те, що Сергій Іринейович встановив у своїх науково-методичних роботах і постійно підкреслював пряму залежність між оволодінням системою первинних знань, умінь і навичок і підвищенням добробуту народу. Ріст добробуту народу він вбачав, передусім, у «розвитку сукупності соціальних особистостей». А такий розвиток можливий тільки завдяки новій системі освіти, основою якої є обов'язковість і загальнодоступність. У розумінні педагога школа тільки тоді стане дійсно корисною суспільству, коли справа навчання стане справою державною для всіх, i сімейною для кожного. I, як наслідок, висловлює цікаві, на наш погляд, ідеї про створення шкіл для дорослих, сільськогосподарських шкіл і шкіл для дівчаток. Через обов'язковість автоматично вирішується питання про єдині навчальні вимоги, статус учня і батьківські обов'язки. Отже, система народної освіти, побудована на принципах загальнодоступності та обов'язковості, здатна докорінно викоренити багато вад суспільства і виправити викривлені погляди заможних його прошарків на шкільну освіту.

У вересні 1876 р. Міністерство розіслало циркулярне розпорядження директорам і інспекторам народних училищ 3 питаннями, що стосуються введення в початкових школах обов'язкового навчання. 3 відповідей директорів і інспекторів народних училищ був складений цілий друкарський том, виданий Міністерством народної просвіти за 1880 р. під заголовком «Матеріали 3 питання про введення обов'язкового навчання в Росії». Вони (матеріали) свідчили про малу кількість як дітей у школах, так і кількість самих шкіл. Але, незважаючи 


\section{Holiuk Oksana, Rodiuk Nataliia}

на об'єктивні потреби суспільства в освіті, Міністерство народної просвіти відмовилося від подальших кроків по введенню в Росії обов'язкового навчання. Відзначивши, що існуюча система земських шкіл занадто дорога для простого народу, Міністерство висловило думку, що і «сам принцип обов'язковості у справі навчання якось не до душі російській людині».

У 90-х роках питання обов'язкового навчання знову постало на порядку денному. Так, у 1896 р. А.С. Ілларіон подав заяву в Державну Думу про введення обов'язкового навчання дітей у місті Харкові. Міське управління, відзначаючи, що окрім бажання необхідно мати i можливості його реалізувати, визнало необхідним розглянути потреби, пов'язані із здійсненням цього питання, розмір необхідних засобів i джерело їх покриття. I тільки коли ці дані будуть отримані, тоді можна просити уряд, i «це прохання матиме форму не платонічного побажання, а глибоко обдуманої і серйозної справи» [14]. 24 вересня 1898 р. Державна Дума обрала комісію з питань про введення загального навчання в Харкові.

Як показало проведене дослідження, питання про введення загального навчання довгий час розроблялося тільки в теоретичному плані. I лише в 1907 році (після смерті C.I. Миропольського), уряд і законодавчі установи приступили до практичного здійснення заходів щодо введення в країні загальної обов'язкової освіти.

Окрім прибічників обов'язкового навчання в педагогічних кругах існували і його затяті супротивники. В якості вагомого аргументу вони висували те, що коли початкова освіта стане долею всіх, без урахування соціального стану, то не буде лакеїв, праль, покоївок і тому подібне, оскільки освічені люди не захочуть йти в служіння, а всі захочуть бути панами. Крім того, школа відірве селянина від землі і змусить шукати легший заробіток.

Супротивники «обов'язковості» були і в уряді. Вони дотримувалися думки, що управляти освіченим народом важче, ніж неосвіченим. Відомий педагог XIX ст. В. Вахтерів на сторінках журналу «Вісника виховання» виступав з різкою критикою подібних поглядів. Дотримуючись думки про відкриття обов'язкових загальноосвітніх шкіл не в інтересах тієї або іншої віри, тієї або іншої спеціальності, а в інтересах народу, він переконливо доводив, що тільки освічений, цивілізований народ «всяку міру, прийняту урядом в інтересах народу, зустріне не 
лише загальним співчуттям і схваленням, але і діяльною підтримкою» [1, с. 1-10]. Такої ж точки зору дотримувався і С.I. Миропольський.

C.I. Миропольский був повністю солідарний з Я.А. Коменським у тому, що для початку навчання найбільш сприятливим є підлітковий вік (7-8 років), оскільки саме 3 цього віку дитина починає жити свідомим життям [7, с. 13-14].

Особливий інтерес викликають і мають певну теоретичну значущість висунені С.I. Миропольським у книзі «Методика навчання письму в народній школі» «дидактичні начала» навчання в народній школі:

1. Збуджувати допитливість і бажання до навчання в дитини, оскільки без бажання навчання йде погано, успіх не є надійним. Учитель стоїть біля дошки, показує і розповідає, а учні позіхають і намагаються швидше втекти від справи. У цьому випадку С.I. Миропольський рекомендував застосувати педагогічний такт, що збуджує в дітях дружну завзятість, і що не дозволяє нікому позіхати в той час, коли треба займатися справою.

2. Уникати марних труднощів, які не під силу дитині, але при цьому строго і послідовно переходити від простого до складного, від легкого до важкого, від відомого до невідомого.

3. Будь-яку важку справу давати потроху, так, щоб учень міг вільно і виразно виконувати ii, а інакше справа не під силу відіб'є бажання у школяра працювати. Для цього С.І. Миропольський вводив «підготовчі вправи».

4. Розвивати в дітях самодіяльність.

5. Прищеплювати дитині добрі шкільні навички, звичку до акуратності, чистоти, справності і порядку; привчати дитину до точної і уважної роботи з самого початку.

6. Організовувати зміни і різноманітність занять, що збуджують увагу дитини.

7. Використовувати хороші способи навчання, однаково зручні як в поодинокому навчанні, так і у великих класах.

8. Набуті дитиною уміння повинні мати практичний характер і «застосування», а виконувані вправи - зрозумілі і осмислені [8, c. 11-14].

Вивчення «дидактичних начал» дозволяє підкреслити особливості поглядів C.I. Миропольського на реалізацію принципів природовід- 


\section{Holiuk Oksana, Rodiuk Nataliia}

повідності, доступності, послідовності, систематичності, врахування вікових особливостей дитини. Як бачимо, всі «начала» тісно переплітаються з принципом самодіяльності в навчанні, що самій дитині дозволяє поступово переростати з об'єкта спеціальних дидактичних дій в суб'єкт, що вільно і усвідомлено оволодіває знаннями.

Підкреслюючи важливість прищеплення дитині «добрих навичок», C.I. Миропольський, $з$ одного боку, звертав увагу на необхідність 3 самого початку вчити дитину «особливому педантизму» в навчальній роботі, з іншого, розуміючи, що такого роду «педантизм» занадто важкий для маленької дитини, - вказував на обов'язковість зміни і різноманітність навчальних занять, використання «хороших способів навчання». Саме завдяки цим вимогам, відзначав педагог, навчальний процес стає повним, вільним від муштри і схоластики.

У педагогіці давно ведуться суперечки про прагматичне навчання як надмірний абсолют практичної спрямованості будь-якого вчення. C.I. Миропольський показав себе «розумним прагматиком», оскільки єдиним критерієм для отриманих знань він вважав уміння їх практичного використання, тим самим міцно зв'язуючи теорію і практику.

Таким чином, зазначені «дидактичні начала» були вагомим внеском в теоретичну розробку дидактики того часу. I, на наш погляд, представляють інтерес і для сучасної педагогічної науки.

Як показав аналіз педагогічної спадщини С.I. Миропольського, він був істинно віруючою, глибоко релігійною людиною. Саме цим пояснюється зв'язок навчання з релігією. Він відзначав, що навчання може досягати своїх високих цілей тільки за допомогою церкви, тому «між школою і церквою має бути тісний живий зв'язок» [7, с. 42]. У книзі «Дидактичні нариси. Учень і виховне навчання в народній школі» C.I. Миропольський писав: «Церква - $є$ училище віри і благочестя для всіх християн; поза церквою немає порятунку; поза церквою не може бути істинного християнського виховання і вчення» [7, с. 42].

Таким чином, C.I. Миропольський, розглядаючи процес навчання як частину цілісного педагогічного процесу, виділяв викладання (діяльність учителя) і навчання (діяльність учнів) в якості його основних взаємозв'язаних сторін. Він обгрунтував етапи засвоєння навчального матеріалу (привертання уваги, організація сприйняття, осмислення, закріплення сприйнятої і засвоєної інформації, контроль знань). 


\section{Pedagogical views of S. Myropolsky on the contents of primary education}

Вважаючи, що в процесі навчання повинні засвоюватися учнями знання, уміння і навички, розвиватися їх пізнавальні здібності, уміння самостійно працювати, C.I. Миропольський тим самим підкреслював важливість і взаємозумовленість трьох функцій навчання: освітньої, розвивальної і виховної. Виділяючи в якості основної мети процесу навчання «усебічне збудження розумової природи дитини», а також «збудження допитливості дітей в якомога більшій кількості напрямів», C.I. Миропольський продовжив розвиток ідей Я.А. Коменського про загальну, безкоштовну, обов'язкову освіту, рівну як для хлопчиків, так і для дівчаток. Специфічним для дидактичних поглядів С.I. Миропольського була постановка перед учителем двох завдань: «охоронного» (не заважати розвитку інтелектуальних інстинктів дитини) і «спрямовуючого» (дати потребі, що пробудилася, матеріал, який сприяв би іiі правильному вихованню).

Ідеї C.I. Миропольського щодо виділення викладання і навчання в якості взаємопов'язаних сторін процесу навчання, важливості і взаємозумовленості освітньої, розвивальної і виховної функцій навчання актуальні і сьогодні.

\section{3. Питання змісту початкової освіти за С.I. Миропольським}

Вивчення педагогічної теорії і шкільної практики минулого показало, що при визначенні змісту освіти допускалося немало помилок, які негативно позначилися на якості навчання. Зміст освіти відставав від рівня науки, виявлявся переобтяженим, тим самим спотворювався характер навчання як чинника розвитку і формування особи [4, с. 11].

Питання змісту освіти займали гідне місце в педагогічній спадщині i C.I. Миропольського. Вони знайшли відображення в таких роботах: «Народна школа за ідеями Коменського» (1873 р.), «Навчання грамоті» (1901р.), «Школа і суспільство. Приватна Харківська жіноча недільна школа» (1892р.). Як і Я.А. Коменський, а також багато його співвітчизників (Х.Д. Алчевська, А.В. Духнович, В.М. Каразін, М.О. Корф та ін.), С.I. Миропольський велику роль надавав просвіті російського народу. Він відзначав, що зневага освітою народжує «огрубілість і здичавіння мас», послабляє силу суспільства, підриває авторитет уряду, веде до анархії і загибелі. I, навпаки, освіта, справедливо підкреслював він, служить потужною єднальною і зміцнюючою силою всіх сфер громадського життя, народжує загальну довіру, збільшує продук- 
тивність країни, ушляхетнює маси і прославляє народний добробут $[2$, с. $95 ; 9$, с. 110$]$.

Особливий інтерес викликає тлумачення С.I. Миропольським поняття «освіченість». Дивлячись на просвіту народу як на глибоке, серйозне і велике завдання, з яким цілком може впоратися народна школа, педагог справедливо вважав, що бути освіченим - це не означає володіти великим обсягом знань, говорити багатьма мовами, необхідно просто усвідомлювати людську гідність і направляти свою діяльність у дусі цієї свідомості. За С.І. Миропольським, освіта є: а) «загальне право людини»; б) «потреба людської природи» (оскільки людина за своєю природою прагне до розвитку, розум її жадає знання, височіє і облагороджується ним); в) борг, «бо порушення його $є$ порушення Божественної волі всіх людей, що призиває до розуму і свободи, до розвитку і досконалості»; г) «загальна вигода людей» [2, с. 95].

У статті «В чому наше завдання» (1873 р.) С.I. Миропольський визначив мету освіти: «зробити людину людиною», тобто прославити людину до iï ідеалу як свідомо діючу, розумно-вільну істоту. Відповідно до цієї мети педагог виділив три мети народної школи: а) «діяти розвивальним чином на всю натуру дитини»; б) «прищепити їй ясні і виразні поняття і знання, що становлять необхідну умову для розумового розвитку людини, пробудити в ній прагнення до самоосвіти»; в) «сприяти вихованню в ній істинно людського характеру» [6, с. 15-16]. Як бачимо, ці завдання припускають органічний взаємозв'язок освіти, розвитку і виховання дитини.

Видатний педагог другої половини XIX століття, виступаючи за рівне отримання освіти як хлопчиків, так і дівчаток, підкреслював несправедливість і «шкідливість» віддалення дівчаток зі школи. Саме жінка, мати і вихователька своїх дітей прищеплює перші навички, створює умови для розвитку, виховання характеру. У роботі «Народна школа за ідеями Коменського» (1873 р.) він писав: «Залишаючи матір неосвіченою, ми засуджуємо на неуцтво всю сім'ю; і навпаки, жінка-мати легко і зручно передає грамотність дітям, i, таким чином, служить кращою помічницею вчителя» [9, с. 111]. Ця позиція педагога і сьогодні не втратила своєї актуальності. Такої точки зору дотримувалися і багато прогресивних діячів того часу. Так, наприклад, у циркулярному листі Обер-прокурор Святійшого Синоду м. Харкова К. Побєдоносцев (12 вересня 1892 р.), звертаючись до Його Велично- 


\section{Pedagogical views of S. Myropolsky on the contents of primary education}

сті з проханням посприяти «можливо ширшому поширенню початкових шкіл», висловлював особливе жалкування за нікчемним відсотком дівчаток, що навчаються [14].

Цікавим є трактування С.I. Миропольським «народної школи». На його думку, вона так називається не тому, що нижча, створена для дітей бідняків, а тому, що вона - таке ж загальне надбання «як повітря, як світло», тому що складає перший і загальний ступінь початкового утворення всього народу. Сергій Іринейович звертав увагу на те, що народна школа $є$ школою освітньою, елементарною, де зникають недоречні відмінності громадського і соціального статусу батьків. Він писав: «Школа народна має бути так організована, щоб у ній однаково могли навчатися діти різних прошарків, усього народу, в цьому сенсі вона є школою народною» [9, с. 114]. Крім того, С.І. Миропольський вказував, що перед народною школою стоять два головні взаємопов'язані завдання: «Вона виховує і навчає дітей, або що теж, коротко, утворює їх» [9, с. 115].

Вважаючи, що в школі розум людини повинен стати освіченим, «воля зміцнитися на добро і серце потягнутися до всього людського», розумна думка стати словом, а слово - справою, С.I. Миропольський підкреслював, що знання служить основою діяльності розвиненої особи. Тому в основу змісту освіти педагог поклав єдність реальної і формальної освіти.

Суть формальної освіти, яка веде свій початок від Локка (XVII ст.) він вбачав у всебічному розвитку психічних сил учня. Реальна освіта, вважав С.І. Миропольський, що становить «вищу якість розумового матеріалу, який повідомляється дітям», не можна обмежити тільки тими предметами, які підлягають зовнішнім почуттям або дають глибоку матеріальну користь. На думку педагога, реальність припускає предмети духовного світу і тотожна $з$ поняттям «істинна дійсність». Ознаками ж реального утворення C.I. Миропольський вважав істинність, здоровий світогляд, розвиненість і міцність розумової і моральної сторони людини. Він вважав, що така реальність безпосередньо i тісно зв'язана із завданнями формальної освіти, оскільки вона збуджує любов до чесної праці, до взаємної допомоги, спонукає, підтримує і направляє людину до самостійних зусиль «вибратися на пряму дорогу, створити собі краще існування, охороняти своє і загальне існування». 
Слід зазначити, що передові російські педагоги XIX століття, такі як М.О. Добролюбов, К.Д. Ушинський, М.Г. Чернишевський, піддавали різкій критиці теорію як формальної, так і реальної освіти. Заслугою С.I. Миропольського $є$ те, що він один 3 перших узяв кращі ідеї обох теорій, об'єднав їх в єдине ціле.

Одним з питань, на які повинен відповідати зміст освіти, $\epsilon$ питання: «чого вчити в школі». На нього С.І. Миропольський, як і Я.А. Коменський, відповідав, що в школі повинні вчити всіх усьому, а не обмежуватися тільки елементарною грамотністю. У початковій школі, на його думку, в стислому і скороченому вигляді повинно бути передано дітям те, що здатне робити їх «істинними людьми», тобто мають бути прищеплені необхідні знання і створені умови всебічного розвитку дитячої природи.

Відмінною рисою підходу С.І. Миропольського до розробки питань змісту освіти $€$ те, що він один з перших в історії педагогічної думки об'єднав воєдино оволодіння системою знань, умінь і навичок і формування морально-християнських, вольових якостей особи. У статті «В чому наше завдання»? (1873р.) Миропольський писав, що в зміст курсу початкової школи повинні органічно входити загальноосвітні елементи, тобто елементи, що «роблять людину людиною», і елементи практичного знання, що готують дитину до життя за певних умов [6, с. 18].

У роботі «Народна школа за ідеями Коменського» С.I. Миропольський визначив засоби «загальнолюдської і національно-практичної освіти». Наприклад, «загальнолюдська освіта» здійснюється за рахунок розумового, естетичного, фізичного виховання адекватними засобами. Так, розумова освіта здійснюватиметься, за переконанням C.I. Миропольського, завдяки грунтовному знайомству з рідною мовою, виразному читанню, письмовому і друкарському слову, мистецтву письма, «рахуванню» на цифрах і рахунках; геометрія в поєднанні з кресленням. До засобів для розвитку волі і характеру він зараховував початкові молитви, вчення віри і християнської моральності, знайомство з богослужінням. Серед засобів естетичного утворення C.I. Миропольський виділяв спів загальновживаних мелодій, основи музики, неважкі п'єси (поодинокі і хором), спів священних гімнів, церковних співів, малювання, геометричне креслення. Фізичний розвиток дітей, на думку Миропольського, забезпечується заняттями гімнастикою, іграми і навчальними прогулянками. 


\section{Pedagogical views of S. Myropolsky on the contents of primary education}

Враховуючи попередній досвід навчання і виховання, С.I. Миропольський довів, що національно-практична освіта повинна досягатися за рахунок: а) знайомства дітей 3 навколишньою природою (вітчизняна географія, відомості з природознавства); б) знайомства 3 минулим рідного народу (вітчизняна історія, твори вітчизняної літератури); в) знайомства 3 основами сучасного життя рідного народу (відомості з області права - юридичні, відомості з області економіки господарські); г) розвитку практичної навички в праці (знайомство 3 обраними ремеслами, практичні відомості з механічних мистецтв). Це була одна 3 перших комплексних розробок структури змісту освіти, для якої був характерний гармонійний зв'язок загальнолюдської і національної освіти (таблиця 1). Причому цей зв'язок стає настільки чутливим і взаємозворотним від одного її елементу до іншого, що правильніше було б говорити про діалектику загальнолюдського, національного і практичного в теорії C.I. Миропольського.

Таблиця 1

\section{C.I. Миропольський про компоненти змісту початкової освіти}

\begin{tabular}{|c|c|c|c|}
\hline \multicolumn{4}{|c|}{ І. Загальнолюдський розвиток } \\
\hline Розумова освіта & $\begin{array}{c}\text { Розвиток волі } \\
\text { і характеру }\end{array}$ & Естетична освіта & $\begin{array}{l}\text { Фізичний } \\
\text { розвиток }\end{array}$ \\
\hline \multicolumn{4}{|c|}{ засоби } \\
\hline $\begin{array}{l}\text { - Рідна мова } \\
\text { - Читання } \\
\text { - Письмо } \\
\text { - Числення } \\
\text { - Геометрія } \\
\text { - Креслення } \\
\end{array}$ & $\begin{array}{l}\text { - Початкові } \\
\text { молитви } \\
\text { - Знайомство } 3 \\
\text { богослужінням }\end{array}$ & $\begin{array}{l}\text { - Спів } \\
\text { - Музика } \\
\text { - Малювання } \\
\text { - Геометричне } \\
\text { креслення }\end{array}$ & $\begin{array}{l}\text { - Гімнастика } \\
\text { - Ігри } \\
\text { - Навчальні прогу- } \\
\text { лянки }\end{array}$ \\
\hline \multicolumn{4}{|c|}{ II. Національно-практична освіта } \\
\hline $\begin{array}{c}\text { Знайомство } \\
3 \text { навколишньою } \\
\text { природою }\end{array}$ & $\begin{array}{c}\text { Знайомство } \\
\text { з минулим } \\
\text { рідного народу }\end{array}$ & $\begin{array}{c}\text { Знайомство } \\
\text { з основами } \\
\text { сучасного життя } \\
\text { рідного народу }\end{array}$ & $\begin{array}{c}\text { Розвиток } \\
\text { практичної } \\
\text { навички в праці }\end{array}$ \\
\hline \multicolumn{4}{|c|}{ засоби } \\
\hline $\begin{array}{l}\text { - Вітчизняна } \\
\text { географія } \\
\text { - Відомості з при- } \\
\text { родознавства }\end{array}$ & $\begin{array}{l}\text { - Вітчизняна } \\
\text { історія } \\
\text { - Твори вітчизня- } \\
\text { ної літератури }\end{array}$ & $\begin{array}{l}\text { - Відомості з } \\
\text { області права } \\
\text { (юридичні) } \\
\text { - Відомості з } \\
\text { області економіки } \\
\text { (господарські) }\end{array}$ & $\begin{array}{l}\text { - Знайомство } 3 \\
\text { ремеслами } \\
\text { - Практичні відо- } \\
\text { мості з механічних } \\
\text { мистецтв }\end{array}$ \\
\hline
\end{tabular}


Звертає на себе увагу те, що головним засобом розвитку характеру виступає релігія з її постійною стриманістю в правах і безліччю доброчесностей. Християнство органічно зливається з науковими знаннями, культурою, вихованням у праці і обов'язковою практичною діяльністю. Таким чином створюється міцне ядро тих якостей, умінь і рис вдачі, без яких становлення особистості стає пустим звуком. У сучасній педагогіці зміст освіти розглядається як педагогічне втілення моделі соціального замовлення, тобто вимоги суспільства до того, що повинен знати і уміти, які якості повинен мати учень.

Як показав аналіз педагогічної спадщини C.I. Миропольського, вимоги, що виділяються ним до змісту освіти, співзвучні із сучасними. Так, у статті «В чому наше завдання» (1873 р.), він висунув у якості вимоги до змісту освіти спрямованість на реалізацію мети зробити «людину людиною», тобто «прославити людину до її ідеалу» [6, с. 51]. Наступна вимога - «створення умов усебічного розвитку дитячої природи» може бути досягнута, на думку C.I. Миропольського, шляхом «учити всіх усьому», а не обмежуватися елементарною грамотністю [9, с. 134].

Своєрідністю відрізняється погляд С.I. Миропольського на практичну і наукову значущість освіти. Він вказував, що предмети повинні входити в початкову школу не як науки, а як «практичні уміння», щоб дитина якнайшвидше отримала насолоду від уміння практичного застосування своїх знань [12, с. 106]. Вимога забезпечення гуманізації освіти повністю, на наш погляд, збігається з сучасною. С.I. Миропольський вважав, що досягти цього можна шляхом включення в зміст освіти матеріалу про минуле рідного народу, його культуру, історію і підвищення статусу таких предметів, як Закон Божий і спів.

Особливу увагу в змісті освіти C.I. Миропольський приділяв необхідності обліку вікових і «природних особливостей» учнів. У роботі «Народна школа за ідеями Коменського» він писав, що «природа людини - це та загальна, постійна і незмінна основа, на яку спирається і з якої витікає елементарний курс народної школи [9, с. 115]. Займаючись розробкою питань змісту освіти, С.І. Миропольський так будував програму навчання, щоб курс кожного року був закінченим, тобто якщо учні з будь-якої причини (а це найчастіше брак коштів) не зможуть продовжувати навчання, то після закінчення кожного року вони «знатимуть принаймні основу всіх предметів» [12, с. 8-9]. 


\section{Pedagogical views of S. Myropolsky on the contents of primary education}

Слід зазначити, що C.I. Миропольський одним з перших у вітчизняній науці вказав на необхідність того, щоб «усі предмети елементарної школи знаходилися в тісному взаємозв'язку один $з$ одним». Він вважав, що зміст освіти повинен розглядатися не як сума окремих предметів, а як певна система навчальних дисциплін. Як бачимо, вимоги до відбору змісту освіти, сформульовані C.I. Миропольським, не лише були вагомим внеском в педагогічну науку досліджуваного періоду, але і не втратили своєї актуальності і на сьогодні (таблиця 2).

Таблиця 2

\section{C.I. Миропольський про вимоги до змісту початкової освіти}

\begin{tabular}{|c|c|}
\hline \multicolumn{2}{|c|}{ Вимоги до змісту освіти } \\
\hline $\begin{array}{c}\text { сформульовані } \\
\text { C.I. Миропольським }[9 ; 12] \\
\end{array}$ & $\begin{array}{c}\text { ті, що існують } \\
\text { у сучасній педагогічній науці }\end{array}$ \\
\hline $\begin{array}{l}\text { - спрямованість на реалізацію мети } \\
\text { зробити «людину людиною» }\end{array}$ & $\begin{array}{l}\text { - спрямованість освіти на реалізацію } \\
\text { мети усебічного розвитку особистості }\end{array}$ \\
\hline \multicolumn{2}{|l|}{$\begin{array}{l}\text {-створення умов усебічного розвитку } \\
\text { дитячої природи }\end{array}$} \\
\hline - практична значущість & $\begin{array}{l}\text { - висока наукова і практична значу- } \\
\text { щість змісту, що включається в основи } \\
\text { наук }\end{array}$ \\
\hline - забезпечення гуманізації освіти & - забезпечення гуманізації освіти \\
\hline $\begin{array}{l}\text { - облік вікових і природних особливос- } \\
\text { тей учнів }\end{array}$ & $\begin{array}{l}\text { - відповідність складності змісту } \\
\text { освіти віковим і реальним навчальним } \\
\text { можливостям учнів }\end{array}$ \\
\hline $\begin{array}{l}\text { - врахування матеріального добробуту } \\
\text { народу }\end{array}$ & $\begin{array}{l}\text {-врахування єдності змістовної і про- } \\
\text { цесуальної сторін навчання }\end{array}$ \\
\hline - врахування міжпредметних зв'язків & - структурна єдність змісту освіти \\
\hline
\end{tabular}

Будучи переконаним в тому, що обсяг матеріалу, що викладається, залежатиме від часу, учителя, умов школи, міри розвитку і віку учнів, що поступають, і так далі, C.I. Миропольський вважав, що окремими предметами викладання повинні стати: Закон Божий, рідна мова, рахунок, геометрія, креслення, спів і гімнастика, а інші - вивчатися по книзі для читання. У силу своїх релігійних переконань основним і найважливішим предметом початкової школи C.I. Миропольський вважав Закон Божий, головне завдання якого він вбачав не в повідомленні знань, а в «доброму вихованні серця і волі людини». Він підкреслював, що цей предмет не лише є головним, але і визначає напрям усього нав- 
чання в школі, а всі інші предмети мають бути поставлені від нього у більш менш тісну залежність. Радив викладати Закон Божий «щиро, правдиво, з сердечною прихильністю» [12, с. 11]. У програму навчання Закону Божого Сергій Іринейович включав вивчення молитов, Священну історію Старого і Нового Завіту, пояснення Богослужіння і Катехізис. Він вважав, що навчання молитвам збуджує в душі дітей потребу в спілкуванні з Богом у слові; Священна історія наповнює душу дітей представленнями 3 духовно-морального світу, 3 життя людей, і збуджує віру в релігійне почуття; Катехізис затверджує в душі основні істини віри, правила християнського життя, вказує «основні надії в любові християнській»; пояснення Богослужіння закликає дітей до благоговійної і розумної участі в церковній молитві, до дотримання церковних звичаїв і правил любові до церкви православної.

Особливу увагу C.I. Миропольський приділяв прищепленню дітям навички жити під дахом і постійним впливом церкви. Це, на його думку, складає «остаточну мету релігійної освіти, що надається дітям у школі, і до неї має бути спрямоване викладання всіх предметів Закону Божого» [12, с. 1].

За силою значущості після вивчення Закону Божого С.I. Миропольський ставив навчання церковному співу, який ототожнював 3 «мовою почуттів», душевних станів, «мовою серця». Церковний спів у початковій школі, як відзначав C.I. Миропольський, знаходячись у тісному зв'язку із Законом Божим, має на меті навчання і зміцнення учнів у церковно-молитовному почутті і потім підготовку учнів до свідомої участі в церковно-громадській молитві, виконання простих співів у церкві і на молитвах вдома і в школі. Маючи на увазі під церковним співом старовинні наспіви, що полягають у церковно-співецьких книгах і вживані при Богослужінні, педагог справедливо вважав, що навчатися співу повинні всі учні, за винятком тих, хто має фізичні недоліки, що перешкоджають співу. Він вважав, що початковий церковний спів не вимагає жодних виняткових музичних дарувань і голосових засобів. Крім того, С.I. Миропольський висловлював думку, що елементарне навчання співу не повинне мати теоретичного характеру, а грунтуватися переважно на практичних вправах, на мелодіях, які б розвивали музичне почуття і заохочували б учнів [13, с. 29-48].

Як показав аналіз педагогічної спадщини С.І. Миропольського, він піддавав різкій критиці погляди тих педагогів, які вважали грамотність 
метою навчання; сам же розглядав грамотність як засіб до подальшої самоосвіти. Основним («формальним») завданням читання вважав вірне розуміння учнями змісту, який виражається в письмових (чи друкарських) знаннях. Він вважав, що читання в дидактичних цілях повинне викладатися одночасно з письмом.

Дослідження показало, що заслугою С.І. Миропольського є і те, що він уперше ввів у науковий обіг і вказав на чотири, на його думку, головні характеристики «естетичного читання»: правильність, свобода (побіжність), свідомість, виразність [13, с. 68; 10, с. 8].

На жаль, у сучасній школі мають місце випадки, що при перевірці уміння читати перевіряють тільки швидкість (побіжність) читання. I якщо правильність і виразність іноді стають об'єктами уваги, то усвідомленість при перевірці читання в молодших класах найчастіше випускається з виду. Тому ситуація, коли дитина, намагаючись збільшити швидкість читання, абсолютно не може відтворити сенс прочитаного, є характерною для практики сучасної школи. Крім того, C.I. Миропольський особливу увагу приділяв підбору книг для читання. Для початкової школи він рекомендував твори Пушкіна, Дмитрієва, Крилова, Хемницера, Кольцова, Нікітіна, Некрасова, Тютчева, Аксакова, Курочкіна, Жуковського, Гоголя, Тургенєва, Толстого, Григоревича, Достоєвського [10, с. 195], що свідчить про гарний літературний смак педагога і про його знання вітчизняної літератури.

Слід зазначити своєрідність позиції С.I. Миропольського щодо арифметики, яку він вважав за необхідне ввести в початкову школу не як науку, а як практичне уміння обчислювати, і тому називав цей предмет «численням». Завданнями навчання «численню», на його думку, мають бути: навчання дітей нумерації, формування умінь свідомо виконувати арифметичні дії і застосовувати їх при вирішенні практичних питань. Він вважав, що навчання численню має освітнє практичне значення. Сергій Іринейович, так само як і В.М. Каразін, який був засновником народної школи для сільських дітей, справедливо підкреслював, що вправи і завдання для «числення» повинні слідувати в систематичному порядку від простих і легких до важчих, а зміст завдань має бути запозичений із сільського побуту і селянської обстановки, щоб не було нужди в сторонніх поясненнях незнайомих дітям предметів [12, с. 104-107].

Таким чином, C.I. Миропольський, виходячи 3 розуміння освіти як «загального права людини», «потреби людської природи», боргу і 
«загальної вигоди людей», визначив мету просвіти і освіти: «зробити людину людиною».

Відкидаючи спробу обмежити школу рамками елементарної грамотності, він виділив триєдину мету народної школи: а) повідомити дитині зрозумілі і виразні поняття, що становлять необхідні умови для розумового розвитку людини, пробудити в ній прагнення до самоосвіти; б) діяти розвиваючим чином на всю натуру дитини; в) сприяти створенню істинно людського характеру. Поклавши в основу змісту освіти єдність реальної і формальної освіти, С.І. Миропольський один 3 перших в історії педагогічної думки об’єднав воєдино такі компоненти змісту освіти, як оволодіння системою знань, умінь і навичок i виховний компонент. Це була одна з комплексних розробок структури змісту освіти, для якої характерний гармонійний зв'язок загальнолюдського і національного виховання.

\section{4. Висновки}

Вивчення педагогічної спадщини С.I. Миропольського, аналіз історико-педагогічної літератури з теми дослідження, архівних документів дозволили встановити внесок педагога в розробку теоретико-практичних питань дидактики.

1. C.I. Миропольський в своїх педагогічних пошуках певною мірою спирався на педагогічні ідеї Я.А. Коменського, а також досягнення прогресивної вітчизняної педагогічної думки, що відображені у працях М.А. Корфа, М.І. Пирогова, В.Я. Стоюніна, К.Д. Ушинського та ін. Він підтримував і розвивав ідеї християнського виховання, загальної освіти, демократизації школи, виховного навчання.

2. Розглядаючи питання освіти у зв'язку з завданнями соціального і морального розвитку суспільства в конкретних історичних умовах, C.I. Миропольський, як і його сучасники, розумів навчання як двобічний процес. Відхиляючи спробу офіційних кіл обмежити школу рамками елементарної грамотності, С.I. Миропольський виділяв триєдину мету народної школи: а) повідомити дитині зрозумілі та чіткі поняття, що складають необхідні умови для розумового розвитку людини, розбудити в ній прагнення до самоосвіти; б) діяти розвиваючим чином на всю натуру дитини; в) сприяти утворенню справжнього людського характеру, що свідчить про важливість і взаємообумовленість трьох функцій навчання - освітньої, розвивальної та виховної. С.І. Миро- 
польський один з перших у вітчизняній педагогіці не відокремлював процес виховання від навчання, ввів у науковий обіг термін «виховне навчання» (1871 р.).

3. C.I. Миропольський, як і більшість його співвітчизників у боротьбі за створення національної школи виступав за позастанову освіту, за рівність дівчаток і хлопчиків в іiі отриманні. Заслугою педагога було: a) включення до змісту освіти компонентів загальнолюдського розвитку (розумова освіта, розвиток волі та характеру, естетична освіта, фізичний розвиток) та елементів національно-практичної освіти (знайомство з оточуючою природою, з минулим рідного народу, з основами сучасного життя рідного народу, розвиток практичних навичок у праці); б) формулювання певних вимог щодо змісту освіти - спрямованість на реалізацію мети «зробити людину людиною», створення умов всебічного розвитку дитячої природи, практична значимість, забезпечення гуманізації освіти, врахування вікових та природних особливостей учнів, врахування матеріального благополуччя народу, врахування міжпредметних зв'язків.

4. Підсумком розробки теоретичних питань, пов'язаних з організацією процесу навчання, стало обгрунтування етапів засвоєння навчального матеріалу та адекватних ним «структурних елементів засвоєння» (привертання уваги, організація сприймання, осмислення, закріплення сприйнятої та засвоєної інформації, контроль знань), а також визначення функцій вчителя в процесі викладання - охороняючу (не заважати розвитку та проявам інтелектуальних інстинктів дитини) та спрямовуючу (подати потрібний матеріал, що сприяв би правильному вихованню).

Теоретичні ідеї, положення, практичні пропозиції С.I. Миропольського щодо теорії навчання, будуть прийнятними за умов реформування змісту освіти на основі посилення його національного компонента, врахування досвіду, накопиченого вітчизняною педагогічною думкою $з$ питань дидактики в системі підготовки вчителів і підвищення їхньої кваліфікації.

\section{Список літератури:}

1. Вахтеров В.П. К вопросу о всеобщем обучении // Вестник воспитания. 1897. - № 1. - C. 1-10.

2. Ельницкий К.В. Русские педагоги второй половины XIX столетия. СПб. : Изд. Д. Полубояринова, 1904. - 167 с. 


\section{Holiuk Oksana, Rodiuk Nataliia}

3. Золотухіна С.Т. Тенденції розвитку виховуючого навчання. - Харків : Основа, 1995. - С. 157.

4. Лозова В.І., Троцко Г.В. Теоретичні основи виховання і навчання. Харків : ОВС, 1997. - 338 с.

5. Миропольский С.И. Воспитание и начальное обучение : руководство для сельских учителей и матерей / Сост. И. Шарловский, Варшава, 1870 г. // Журнал Министерства Народного Просвещения. - 1871. - № 153. - С. 103-108.

6. Миропольский С.И. Гимнастика в народной школе // Семья и школа. $-1876 .-$ Т. 1 - С. 28-45.

7. Миропольский С.И. Доклад в первом заседании «учредительной и редакционной комиссии» С.-Петербургского Педагогического Общества 4 октября 1872 // Семья и школа. - 1873. - № 3. - С. 40-50.

8. Миропольский С.И. Методика обучения письму в народной школе. СПб. : Изд. Костомина, 1884. - 116 с.

9. Миропольский С.И. Народная школа по идеям Коменского // Наша начальная школа. - 1873. - № 3. - С. 102-146; № 4-5. - С. 270-333; № 6. - С. 29-101.

10. Миропольский С.И. Обучение грамоте. - 4-е изд., вновь пересмотр. и исправ. - СПб. : Тип. Глазунова, 1891. - 206 с.

11. Миропольский С.И. Современное состояние вопроса об обязательности обучения в России // Семья и школа. - 1876. - № 6. - С. 253-312; № 7. - С. 315-378.

12. Миропольский С.И. Учебник дидактики. Методика предметов обучения в начальной школе. - СПб. : Изд. Скороходова, 1901. - 121 с.

13. Миропольский С.И. Учебник дидактики. Часть вторая практическая. 3-е изд. - СПб. : Изд. Скороходова, 1905. - 124 с.

14. Тишик O.А. Проблеми дидактики в педагогічній спадщині C.I. Миропольського: автореф. дис. ... канд. пед. наук: спец. 13.00.01 - Теорія та історія педагогіки / О.А. Тишик. - Харків, 1998. - 20 с.

\section{References:}

1. Vakhterov V.P. (1897) K voprosu o vseobshchem obuchenii [On the issue of universal education]. Herald of education, no. 1, pp. 1-10.

2. Elnitsky K.V. (1904) Russkie pedagogi vtoroy poloviny XIX stoletiya [Russian educators of the second half of the XIX century]. St. Petersburg: D. Poluboyarinov's Publishing House. (in Russian)

3. Zolotukhina S.T. (1995) Tendentsii rozvytku vykhovuiuchoho navchannia [Trends in the development of educational training]. Kharkiv: Osnova. (in Ukrainian)

4. Lozova V.I., Trotsko H.V. (1997) Teoretychni osnovy vykhovannia $i$ navchannia [Theoretical foundations of education and training]. Kharkiv: OVS. (in Ukrainian)

5. Myropolsky S.I. (1871) Vospitanie i nachal'noe obuchenie: rukovodstvo dlya sel'skikh uchiteley i materey [Upbringing and primary education: a guide for rural teachers and mothers]. Journal of the Ministry of National Education, no. 153, pp. 103-108.

6. Myropolsky S.I. (1876) Gimnastika v narodnoy shkole [Gymnastics in the public school]. Family and school, vol. 1, pp. 28-45. 


\section{Pedagogical views of S. Myropolsky on the contents of primary education}

7. Myropolsky S.I. (1873) Doklad v pervom zasedanii “uchreditel'noy i redaktsionnoy komissii" S.-Peterburgskogo Pedagogicheskogo Obshchestva 4 oktyabrya 1872 [Report in the first meeting of the "constituent and editorial commission" of the St. Petersburg Pedagogical Society on October 4, 1872]. Family and school, no. 3, pp. 40-50.

8. Myropolsky S.I. (1909) Metodika obucheniya pis'mu v narodnoy shkole [Methodology of teaching writing in popular school]. St. Petersburg: Kostomin's Publishing House. (in Russian)

9. Myropolsky S.I. (1873) Narodnaya shkola po ideyam Komenskogo [Popular school on the ideas of Komensky]. Our Primary School, no. 3, pp. 102-146; no. 4-5, pp. 270-333; no. 6, pp. 29-101.

10. Myropolsky S.I. (1891) Obuchenie gramote [Literacy training]. St. Petersburg: Glazunov's Printing House. (in Russian)

11. Myropolsky S.I. (1876) Sovremennoe sostoyanie voprosa ob obyazatel'nosti obucheniya $\mathrm{v}$ Rossii [The current state of the issue of compulsory education in Russia]. Family and school, no. 6, pp. 253-312; no. 7, pp. 315-378.

12. Myropolsky S.I. (1901) Uchebnik didaktiki. Metodika predmetov obucheniya $v$ nachal'noy shkole [Textbook of didactics. Methodology of teaching subjects in elementary school]. St. Petersburg: Skorokhodov`s Publishing House. (in Russian)

13. Myropolsky S.I. (1905) Uchebnik didaktiki. Chast' vtoraya prakticheskaya [Textbook of didactics. Part two, practical]. St. Petersburg: Skorokhodov`s Publishing House. (in Russian)

14. Tishik O.A. (1998) Problemy dydaktyky $v$ pedahohichnii spadshchyni S.I. Myropolskoho [Problems of didactics in pedagogical heritage S.I. Myropolsky] (PhD Thesis), Kharkiv : Kharkiv State Pedagogical University of Grigory Skovoroda. 